Transactions of the American Fisheries Society, Volume 129, Issue 4 (July 2000), pp. 1044 1059.

http://afs.allenpress.com

http://afs.allenpress.com/archive/1548-8659/129/4/pdf/i1548-8659-129-4-1044.pdf

Online ISSN: 1548-8659

Print ISSN: 0002-8487

DOI: 10.1577/1548-8659(2000)129<1044:EHLARS>2.3.CO;2

(C) American Fisheries Society 


\title{
Evaluating How Local- and Regional-Scale Processes Interact to Regulate Growth of Age-0 Largemouth Bass
}

\author{
James E. Garvey, ${ }^{* 1}$ Russell A. Wright, ${ }^{2}$ Roy A. Stein, AND \\ KRISTEN H. FERRY ${ }^{3}$ \\ Aquatic Ecology Laboratory, Department of Evolution, Ecology, and Organismal Biology, \\ The Ohio State University, Columbus, Ohio 43212-1156, USA
}

\begin{abstract}
Regional- and local-scale processes may interact to influence early growth and survival, thereby governing cohort strength. During summer through fall 1994-1996, we assessed how precipitation (a regional-scale process) and prey availability (a local-scale process) influenced piscivory and growth of age-0 largemouth bass Micropterus salmoides in five Ohio reservoirs (190-1,145 ha). We expected early growth to vary with the abundance and relative sizes of age0 gizzard shad Dorosoma cepedianum. We collected age-0 largemouth bass and prey fishes every 3 weeks in each reservoir. In 1994, May precipitation was low (total $=4 \mathrm{~cm}$ ), resulting in low mean daily reservoir discharge $\left(\bar{x}_{5 \text { reservoirs }}=3.6 \mathrm{~m}^{3} / \mathrm{s}\right)$. In four reservoirs, stable water levels may have led to successful largemouth bass reproduction and perhaps an early hatch. As such, age-0 largemouth bass in these systems were abundant, consumed gizzard shad, and reached large sizes by fall $(15.3 \mathrm{~g})$. In 1995 and 1996, high precipitation (total $>12 \mathrm{~cm}$ ) and high reservoir discharge $\left[\bar{x}_{5 \text { reservoirs }}=13.8 \mathrm{~m}^{3} / \mathrm{s}(1995), 28.8 \mathrm{~m}^{3} / \mathrm{s}\right.$ (1996) $]$ in some reservoirs in May likely reduced largemouth bass abundances. Growth during these years was density dependent across reservoirs. When age-0 largemouth bass abundance was low, nonshad prey fish were consumed, and mean fall sizes were similar to those in 1994 (12.0 g). Conversely, fall weights (4.5-7.4 g) declined in reservoirs with increasing largemouth bass density. Surveying May precipitation in Ohio across 48 years revealed that conditions like those in 1994 occurred less than $15 \%$ of the time. Because gizzard shad should rarely be available and other prey fish species probably are limited, density-dependent processes should often regulate early piscivory, growth, and potentially, cohort strength in these systems.
\end{abstract}

To wisely manage exploited fish stocks, we must continually strive to improve our understanding of population dynamics. As a first step, we must determine the proper scale of inquiry, a topic of continued debate (see Carpenter 1999; Drenner and Mazumder 1999 for a general discussion). For marine ecologists interested in understanding fish population dynamics, scale-dependent processes have long been recognized as important (Leggett et al. 1984; Rose and Leggett 1990; Chambers and Trippel 1997). In freshwater, lentic systems, regional (i.e., among-system) and local (i.e., withinsystem) scale factors also regulate biotic interactions (e.g., Tonn et al. 1990). However, because populations are isolated within individual lakes,

\footnotetext{
* Corresponding author: jgarvey @ ksu.edu

${ }^{1}$ Present address: Division of Biology, Kansas State University, Manhattan, Kansas 66502, USA.

2 Present address: Department of Fisheries and Allied Aquacultures, Auburn University, Auburn, Alabama 36849, USA.

${ }^{3}$ Present address: Department of Forestry and Wildlife Management, University of Massachusetts, Amherst, Massachusetts 01003, USA.

Received June 23, 1999; accepted March 10, 2000
}

local-scale processes typically receive more attention than regional ones. Given this asymmetry, we sought to understand how abiotic and biotic processes acting at both regional and local scales interact to influence fish assemblages in reservoirs, the predominant lentic systems between 30 and $42^{\circ}$ $\mathrm{N}$ latitude (with the exception of Florida; Thornton 1990).

Most would agree that fluctuations in adult abundances are directly linked to variability in recruitment from early to older life stages and that our ability to predict responses of populations to perturbations such as exploitation depends on our ability to forecast recruitment (Forney 1976; Hilborn et al. 1995; Chambers and Trippel 1997). Hence, in both marine and freshwater systems, delineating mechanisms underlying first-year growth and survival of fishes has been a priority. We explored regional- and local-scale mechanisms that influence cohort strength of age-0 largemouth bass Micropterus salmoides, an economically important sportfish throughout North America and a keystone species in some ecosystems (e.g., Mittelbach et al. 1995).

During the first year of life, foraging success of largemouth bass is limited by the size of prey rel- 
TABLE 1. - Characteristics of Ohio reservoirs in which we explored potential factors influencing early growth of age0 largemouth bass (LMB) during 1994-1996. Typical gizzard shad densities derive from ranges documented in reservoirs during 1992-1994 (Dettmers and Stein 1996; Bremigan 1997), assuming that larval densities reflect juvenile densities available to largemouth bass. However, larval survival is typically higher in reservoirs with total phosphorus concentrations greater than $100 \mu \mathrm{g} / \mathrm{L}$ (Bremigan 1997), most likely leading to higher juvenile densities in these systems. Total $\mathrm{P}$ was quantified in 1993, 1994 or both years (Bremigan 1997).

\begin{tabular}{|c|c|c|c|c|c|}
\hline Reservoir & County & $\begin{array}{c}\text { Surface } \\
\text { area (ha) }\end{array}$ & $\begin{array}{l}\text { Watershed } \\
\text { area : surface } \\
\text { area ratio }\end{array}$ & $\begin{array}{l}\text { Typical } \\
\text { total P } \\
(\mu \mathrm{g} / \mathrm{L})\end{array}$ & $\begin{array}{c}\text { Typical age-0 } \\
\text { gizzard shad } \\
\text { density } \\
\left(\text { larvae } / \mathrm{m}^{3}\right)\end{array}$ \\
\hline Caesar Creek & Warren, Clinton & 1,145 & 54 & 50 & $10-19$ \\
\hline Delaware & Delaware, Marion, Morrow & 526 & 188 & 200 & $>19$ \\
\hline Knox & Knox & 192 & 41 & 50 & $>19$ \\
\hline Pleasant Hill & Richland, Ashland & 344 & 148 & 100 & $>19$ \\
\hline Tappan & Harrison & 951 & 19 & 70 & $<10$ \\
\hline
\end{tabular}

ative to their individual gapes, as is common for many fishes (Schael et al. 1991; Bremigan and Stein 1994; Juanes 1994). Early in ontogeny, largemouth bass may compete with fish species that serve as prey for adults, until they reach sizes where they can consume fish prey (Olson et al. 1995). Both regional and local effects likely influence these early size-structured interactions and the relative success of species.

In many reservoirs, growth during early ontogenetic stages of largemouth bass may be driven by the availability of a common prey species, gizzard shad Dorosoma cepedianum. In small, highly productive systems, gizzard shad may reduce abundances of alternative prey fish species through exploitative competition that occurs during early life stages (DeVries and Stein 1992; Stein et al. 1995; Garvey et al. 1998a; Garvey and Stein 1998a). Although juvenile gizzard shad often rapidly outgrow their vulnerability (Hambright et al. 1991; Garvey and Stein 1998b), they can facilitate the piscivorous switch and enhance growth of age0 largemouth bass if they remain susceptible to predation (Adams et al. 1982; Adams and DeAngelis 1987; Garvey and Stein 1998b). Thus, gizzard shad may exert an indirect, negative effect on largemouth bass by limiting alternative prey fish or a direct, positive effect by enhancing growth.

Processes acting at regional (e.g., climate) and local (e.g., prey fish production) scales may well interact to influence early growth and, potentially, cohort strength of largemouth bass, particularly if size translates to increased survival during winter (Garvey et al. 1998c). To explore regional effects on size-structured interactions between largemouth bass and their prey in five Ohio reservoirs, we exploited natural variation in spring precipitation, a factor that may interact with local reservoir hydrology to (1) affect production of age-
0 largemouth bass by altering adult reproductive success and (2) regulate biotic interactions by altering the timing of appearance of species. Because gizzard shad is a strongly interacting species in reservoir food webs (Stein et al. 1995, 1996), we chose reservoirs that varied along a gradient from low to high historical gizzard shad production. By addressing our questions at an ecosystem level, we further our understanding of how ecological systems respond to interacting regional and local processes. From a management viewpoint, we can determine if strategies for sustaining fishery resources should be directed regionally among lentic systems or if problems must be addressed on a system-specific basis.

\section{Methods}

Study reservoirs. - We explored how abiotic and biotic factors interacted to influence growth of age0 largemouth bass in five Ohio reservoirs during spring through fall 1994, 1995, and 1996 (Table 1). Reservoirs spanned a gradient of productivity (total phosphorus) and watershed area: surface area ratio (henceforth called relative watershed area), a factor that likely influences reservoir discharge and water level responses to spring precipitation (Table 1). Reservoirs also varied historically in production of age-0 gizzard shad, a potentially important prey fish (Table 1).

Temperatures were recorded three to five times daily in each reservoir with HoboTemp data loggers placed $1 \mathrm{~m}$ deep. Because warm water temperatures exceeding the optimum for growth of largemouth bass $\left(26^{\circ} \mathrm{C}\right.$; Hanson et al. 1997) may reduce growth rates, we determined the proportion of days between 1 June and 30 September during each year that exceeded this temperature in each reservoir. These proportions were compared across years using a one-way analysis of variance (AN- 
OVA), treating reservoirs as replicates. All statistical tests were considered significant at $P \leq 0.05$; those yielding $0.10 \leq P<0.05$ were reported as marginally significant (Type III sums of squares; SAS 1990). When necessary, we transformed data to meet assumptions of normality. Only significant interactions were included in statistical models.

Daily precipitation data from two weather stations located near the southern and northern boundaries of the area encompassing the study reservoirs were obtained from the National Weather Service. If patterns of precipitation corresponded closely between them, watersheds containing reservoirs probably experienced similar precipitation patterns. We calculated the total rainfall in May, the month of peak spawning for largemouth bass in Ohio (Garvey et al. 1998d). Because spring water movement and water level fluctuations in reservoirs may affect fish spawning, we obtained average daily discharge $\left(\mathrm{m}^{3} / \mathrm{s}\right)$ and water level $(\mathrm{m})$ data for four of the reservoirs in May from the Army Corps of Engineers. For each reservoir, we created an index of May water level variation, which was the standard deviation of the daily water level averaged across all days. For Knox Lake, both discharge and water fluctuation data were unavailable. Thus, we obtained discharge data from a U.S. Geological Survey gauging station in the same subwatershed as Knox Lake (Walhonding River). We used linear regression to determine if discharge and water level fluctuations were related in the four reservoirs in which data were available. Multiple regression was used to determine if precipitation and relative watershed area influenced discharge.

Sampling.-Age-0 largemouth bass were sampled using shoreline electrofishing (at least 100 min effort per date) and inshore seining (10-m bag seine with $3 \mathrm{~mm}$ mesh; at least three 25 -m transects per reservoir) in each reservoir every 3 weeks during June through October. Fish catch per effort (CPE) was quantified as number of fish captured per standardized transect length (seining) or minutes of electrofishing. All individuals were measured (mm total length). In addition, $40-95 \%$ of the individuals per reservoir and date were weighed with measurements stratified by length. Ages of largemouth bass were verified with scales (DeVries and Frie 1996). All prey fishes that were captured by seining were identified to species and measured. We tested the null hypothesis that prey CPE did not differ among reservoirs and years or through time using repeated measures ANOVA.

Growth.-Both growth rates and individual siz- es of age-0 largemouth bass can vary dramatically among systems (Adams et al. 1982). We estimated growth among reservoirs and years by calculating growth rates, standardized fall weights, and the 95th percentile value in fall weight-frequency distributions. For each date, weights of unweighed largemouth bass were estimated using least squares regression models derived from $\log _{e}(x)$ transformed lengths and weights of largemouth bass measured on the same date. All models were significant at $P<0.05$ with ranges of $r^{2}$ values from 0.70 to 0.99 , in which $92 \%$ of $r^{2}$ values were greater than 0.85 . Growth rates $\left(\mathrm{g} \cdot \mathrm{g}^{-1} \cdot \mathrm{d}^{-1}\right)$ were estimated using an exponential model of growth, only including data until 15 October. After 15 October, catch rates of large fish declined, most likely due to habitat shifts as water temperature cooled (see Garvey and Stein 1998b). To determine if fall weights differed among reservoirs and years, we used exponential growth models for each reservoir and year to calculate individual sizes on 15 September, only including individuals captured on the closest sampling date (generally, \pm 1 week). We used a two-way ANOVA to test how reservoir and year affected fall weight. Pairwise comparisons among significant means were made with a Tukey's post hoc multiple comparisons test.

Diets and overlap.-Diet items within a subsample (at least 25 largemouth bass per reservoir and date) of frozen largemouth bass were identified to Family when possible and counted (Stahl and Stein 1994). To estimate diet item biomass, we quantified body dimensions (usually head capsule size or body length) and used corresponding lengthweight relationships (zooplankton: Culver et al. 1985; Dumont et al. 1995; macrobenthos: Smock 1980; G. Mittelbach Kellogg Biological Station, unpublished data; fish: Wahl and Stein 1991) for all taxa to estimate total biomass (mg dry weight) for each sample. If mostly digested, fish in diets were identified using vertebral counts unique to each species (Holland-Bartels et al. 1990). We determined whether the proportion of fish biomass in largemouth bass diets differed among dates, reservoirs, and years with a repeated measures ANOVA. To determine if the relative proportion of prey fish taxa in largemouth diets differed among years, we conducted a $G$ test of independence for each reservoir (Sokal and Rohlf 1981). Potential overlap between largemouth bass and prey was determined by assuming that gizzard shad that were $50 \%$ of largemouth bass total lengths were vulnerable (Michaletz 1997). The null hypothesis that the proportion of gizzard shad vulnerable to 
largemouth bass of mean and median lengths did not differ among dates, reservoirs, or years was tested with an analysis of covariance (ANCOVA), in which date was the covariate. All proportions were arcsine-square-root-transformed before analysis.

General patterns.-Although we initially predicted that precipitation and gizzard shad abundance would primarily affect largemouth bass growth and abundance, several abiotic and biotic factors likely contributed to characteristics of age0 largemouth bass cohorts. Discharge and water level fluctuations may reduce age-0 largemouth bass densities by disrupting adult reproduction. We explored these potential functional relationships using linear regression and a nonparametric, twodimensional Kolmogorov-Smirnov test (2DKS) that detects changes in variance within bivariate distributions (Garvey et al. 1998b). Exact $P$ values for the $2 \mathrm{DKS}$ were generated by rerandomizing the original data 5,000 times and comparing a randomly generated test statistic, $D$, to the $D$ generated for the observed data pairs (Garvey et al. 1998b).

We conducted a principle components analysis (PCA) to assess the relative contribution of 14 potentially interrelated variables to yield observed patterns of largemouth bass density and growth Abiotic variables were total May precipitation, mean May water temperature, mean summer water temperature (1 June-30 September), relative watershed area, and discharge. Biotic variables that were sampled on multiple dates were averaged across dates within each reservoir and year and then included in the PCA. Largemouth bass mean $\mathrm{CPE}$, growth rates, fall weights, and 95 th percentile fall weights were included. Both the mean proportion of fish biomass in largemouth bass diets plus the mean proportion of largemouth bass containing gizzard shad in diets were included. We also included mean gizzard shad CPE and mean prey fish CPE in the PCA. Only principle components with eigenvalues $>1$ were evaluated.

\section{Results}

\section{Abiotic Patterns}

During each year, average monthly temperatures ranged $17-22^{\circ} \mathrm{C}, 20-24^{\circ} \mathrm{C}, 24-26^{\circ} \mathrm{C}, 24-28^{\circ} \mathrm{C}$, and $21-24^{\circ} \mathrm{C}$ in May, June, July, August, and September, respectively. The mean proportion $\pm \mathrm{SE}$ of days where temperature exceeded the optimum for largemouth bass growth was $0.22 \pm 0.05,0.35$ \pm 0.06 , and $0.17 \pm 0.12$ for 1994,1995 , and 1996 , respectively, and did not differ among years [ANOVA: not significant (NS)]. Total May precipitation at southern and northern weather stations was nearly perfectly correlated among years $(r=1.0$; $N=3, P=0.0005)$. Hence, patterns of precipitation were likely similar across the region encompassing the reservoirs. For the four reservoirs in which water levels were quantified, the index of water level variation in May increased with increasing mean May daily discharge (Figure $1 ; r^{2}$ $=0.82, P=0.0001)$, suggesting that discharge and water level changes are linked in these systems. May discharge in reservoirs increased with precipitation and with increased relative watershed area (Figure 2; $R^{2}=0.68$; precipitation, $P=$ 0.0008 ; ratio, $P=0.03$ ). Hence, in 1994 when precipitation was low, discharge was relatively low among reservoirs (Figure 2). During 1995 and 1996 when precipitation was high, discharge, and thus the extent of water level fluctuations, responded least in the reservoir with the smallest relative watershed area (e.g., Tappan) and most in the systems with relatively large watersheds (e.g., Delaware; Figure 2).

\section{Growth Patterns}

Growth rates $\left(\mathrm{g} \cdot \mathrm{g}^{-1} \cdot \mathrm{d}^{-1}\right.$; all regressions: $P<$ $0.05)$ varied among reservoirs, with no consistent pattern arising among years (Figure 3; ANOVA: NS). Conversely, wet weights of largemouth bass estimated to a common fall date (15 September) using exponential growth equations did differ among reservoirs and years (Figure 3; ANOVA: reservoir, $F=19.2$, df $4,1,222, P=0.0001$; year, $F=20.6$, df $2,1,222, P=0.0001)$. Mean wet weight in Knox was greater than in other systems except Delaware, where weights were equivalent (Figure 3; Tukey's studentized range, $P<0.05$ ). Delaware largemouth bass were heavier than those in Pleasant Hill and Tappan (Figure 3; Tukey's studentized range, $P<0.05$ ). Wet weights in Caesar Creek were greater than those in Pleasant Hill or Tappan, whereas weights in Pleasant Hill and Tappan were similar (Figure 3; Tukey's studentized range, $P<0.05)$. Across years, wet weights were ordered from greatest to least: 1994, 1996, 1995 (Figure 3; Tukey's studentized range, $P<$ 0.05). A reservoir $\times$ year interaction occurred, probably because weights differed more across years in some reservoirs (e.g., Pleasant Hill and Knox) than in others (e.g., Caesar Creek; Figure 3; ANOVA: reservoir $\times$ year, $F=15.4$, df 8, $1,222, P=0.0001)$. Fall weights in the 95 th percentile of distributions in reservoirs were posi- 


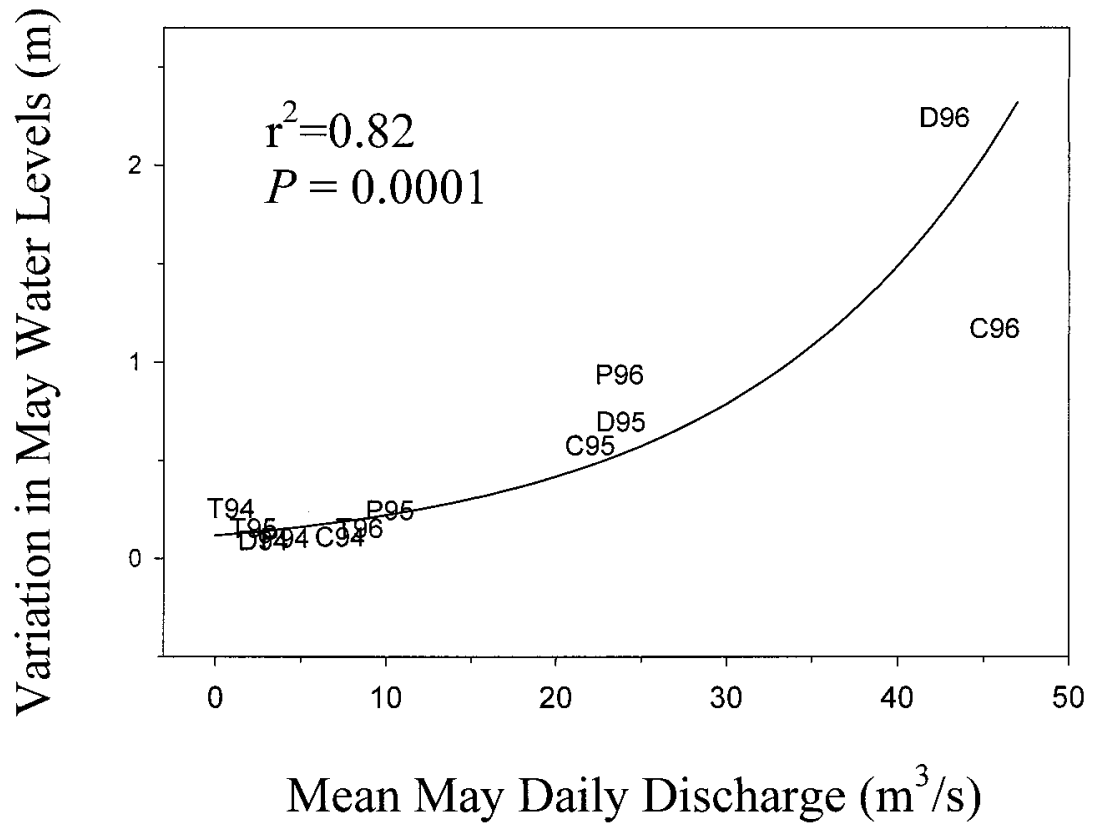

Figure 1.-Positive linear relationship between index of water level fluctuations (i.e., SD of the mean daily water level) and mean daily discharge in four Ohio reservoirs during May 1994, 1995, and 1996, described by water level variation $=0.117 e^{(0.0635 \text {-discharge })}$. Reservoir codes correspond to the first letter of the reservoir name $(\mathrm{P}$, Pleasant Hill; C, Caesar Creek; D, Delaware; and T, Tappan) plus the last two digits of the year.

tively correlated with mean weights (Figure 3; $r$ $=0.86, P=0.0001)$. Thus, systems producing large mean sizes of largemouth bass also produced the largest individuals. Although growth rates did not differ among years, both average and extreme fall weights were generally greatest in 1994 when May precipitation was lowest, although the extent of differences among years was reservoir dependent.

\section{Prey Fish}

Gizzard shad abundance, as estimated by seining CPE, differed among reservoirs but not years (Figure 4; repeated measures ANOVA: reservoir, $F=$ 8.3, df 4, 48, $P=0.0001$; year, $F=2.2$, df 2,48 , $P=0.12$ ). Differences among reservoirs likely occurred because gizzard shad abundances were higher in Knox and Pleasant Hill than in other systems (Figure 4). Gizzard shad abundances depended on sampling week, likely because CPE declined through time (Figure 4; repeated measures ANOVA: time, $F=8.3$, df $4,192, P=0.02)$. A time $\times$ reservoir interaction occurred because the change in gizzard shad abundance differed among reservoirs (Figure 4; repeated measures ANOVA: time $\times$ reservoir, $F=2.8$, df $16,192, P=0.01)$. The absence of a difference among years suggests that gizzard shad abundances were relatively unaffected by the prevailing interannual differences in precipitation. A lack of inter- annual variation in gizzard shad abundance potentially reduced the ability to detect influences on largemouth bass growth.

Abundances of other prey fishes also differed among reservoirs but not years (Figure 4; repeated measures ANOVA: reservoir, $F=3.9$, df 4, 48, $P$ $=0.009$; year, $F=2.1$, df $2,48, P=0.13$ ). Differences were probably driven by the greater $\mathrm{CPE}$ of prey fish in Tappan and Pleasant Hill than in the other reservoirs. Prey fish CPE depended on time (Figure 4; repeated measures ANOVA: time, $F=4.2$, df $4,192, P=0.005)$. No interactions between the time effect and the reservoir or year effects suggest that these differences were consistent among reservoirs and years (Figure 4). As with gizzard shad, prey fish abundances depended on reservoir-specific characteristics rather than differences in precipitation or other factors among years.

\section{Diets and Prey Overlap}

The proportion of fish biomass in diets of age0 largemouth bass differed among reservoirs and changed with time (Figure 5; repeated measures ANOVA: reservoir, $F=8.1$, df $4,54, P=0.0001$; 


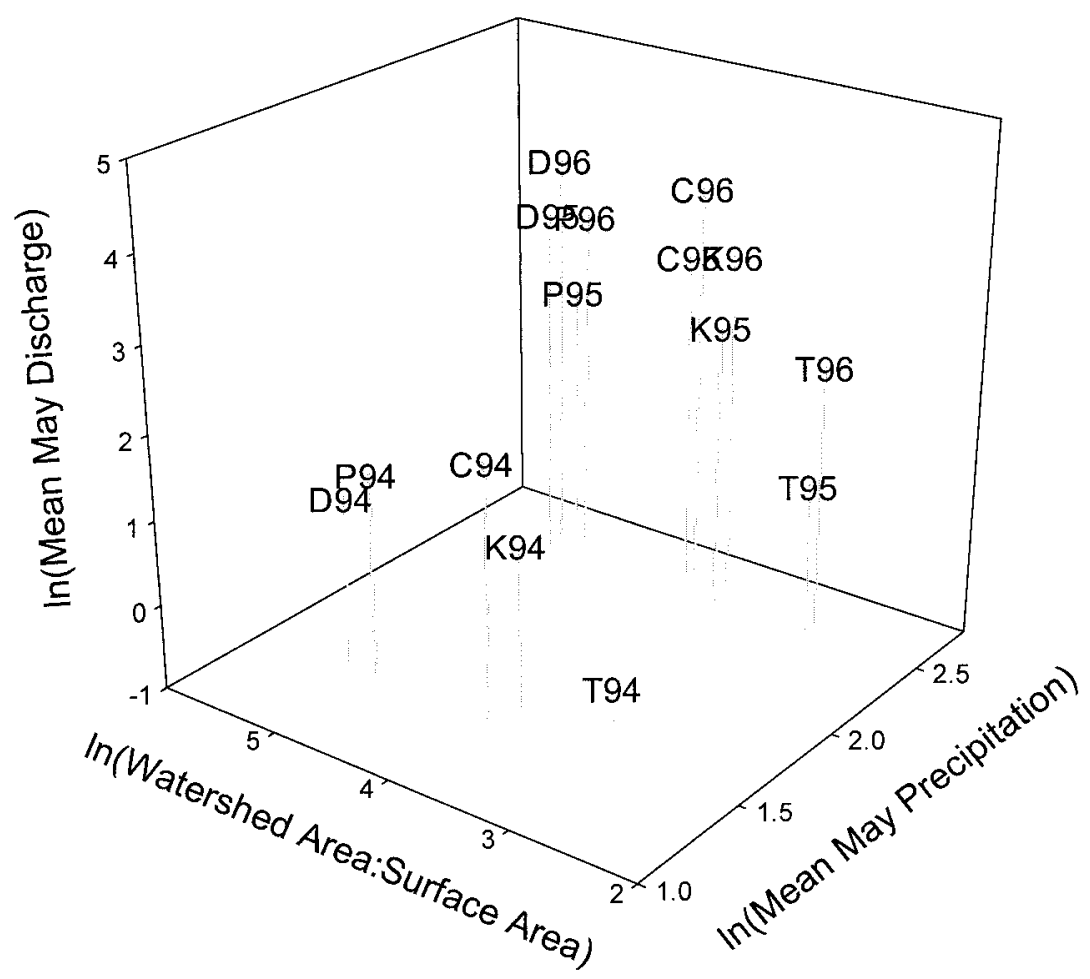

FIGURE 2.-Effect of $\log _{e}(x)$-transformed mean May precipitation (total $\mathrm{cm}$ ) and ratio of watershed area : reservoir surface area (ha) on $\log _{e}(x)$-transformed mean discharge $\left(\mathrm{m}^{3} / \mathrm{s}\right)$ in five Ohio reservoirs during May 1994, 1995, and 1996. Reservoir codes are the same as in Figure 1, with the addition of K, Knox Lake.

time, $F=8.7$, df $2,108, P=0.0004)$. The proportion of fish biomass also differed among years (Figure 5; repeated measures ANOVA: year, $F=$ 27.6, df 2, 54, $P=0.0001)$; fish biomass in diets was generally higher in 1994 than in other years. No interactions among effects occurred.

Restricting our analysis to piscivorous age-0 largemouth bass, the proportion of largemouth bass consuming gizzard shad depended on year in Caesar Creek and Delaware reservoirs ( $G$ test, $P$ $<0.001$; Table 2), where gizzard shad were present in a large proportion of diets only in 1994 (Table 2). In Knox Lake, the proportion of gizzard shad in diets was independent of year ( $G$ test, NS; Table 2 ). The proportion of gizzard shad in diets differed among years in Pleasant Hill, with the greatest contribution occurring in 1994 ( $G$ test, $P<0.001$; Table 2). In Tappan Lake, gizzard shad were present in a low proportion of diets during all years ( $G$ test, NS; Table 2). In the absence of gizzard shad, most piscivorous largemouth bass consumed minnows Pimephales spp., brook silversides Labidesthes sicculus, and sunfish Lepomis spp. In summary, with the exception of Tappan Lake, giz- zard shad were responsible for the high fish biomass in 1994 diets. During the remaining years, other prey fish contributed to diets (i.e., in Caesar Creek and Delaware).

The relatively large contribution of gizzard shad to largemouth bass diets in 1994 in some of the reservoirs may have been related to their sizedependent vulnerability. However, the proportion of gizzard shad vulnerable to either age-0 largemouth bass of median or 95th percentile lengths did not differ among dates, years, or reservoirs (ANCOVAs for median and 95th percentile lengths, NS), probably because proportion overlap varied considerably among dates (mean proportion overlap \pm SD across reservoirs, dates, and years: median $=0.088 \pm 0.23 ; 95$ th percentile $=0.24$ $\pm 0.33)$.

\section{General Patterns}

High discharge and water fluctuations may have negatively affected largemouth bass reproductive success. Age-0 largemouth bass mean CPE declined with increasing discharge (Figure $6 ; r^{2}=$ $0.27, P=0.03)$. A threshold change in the distri- 


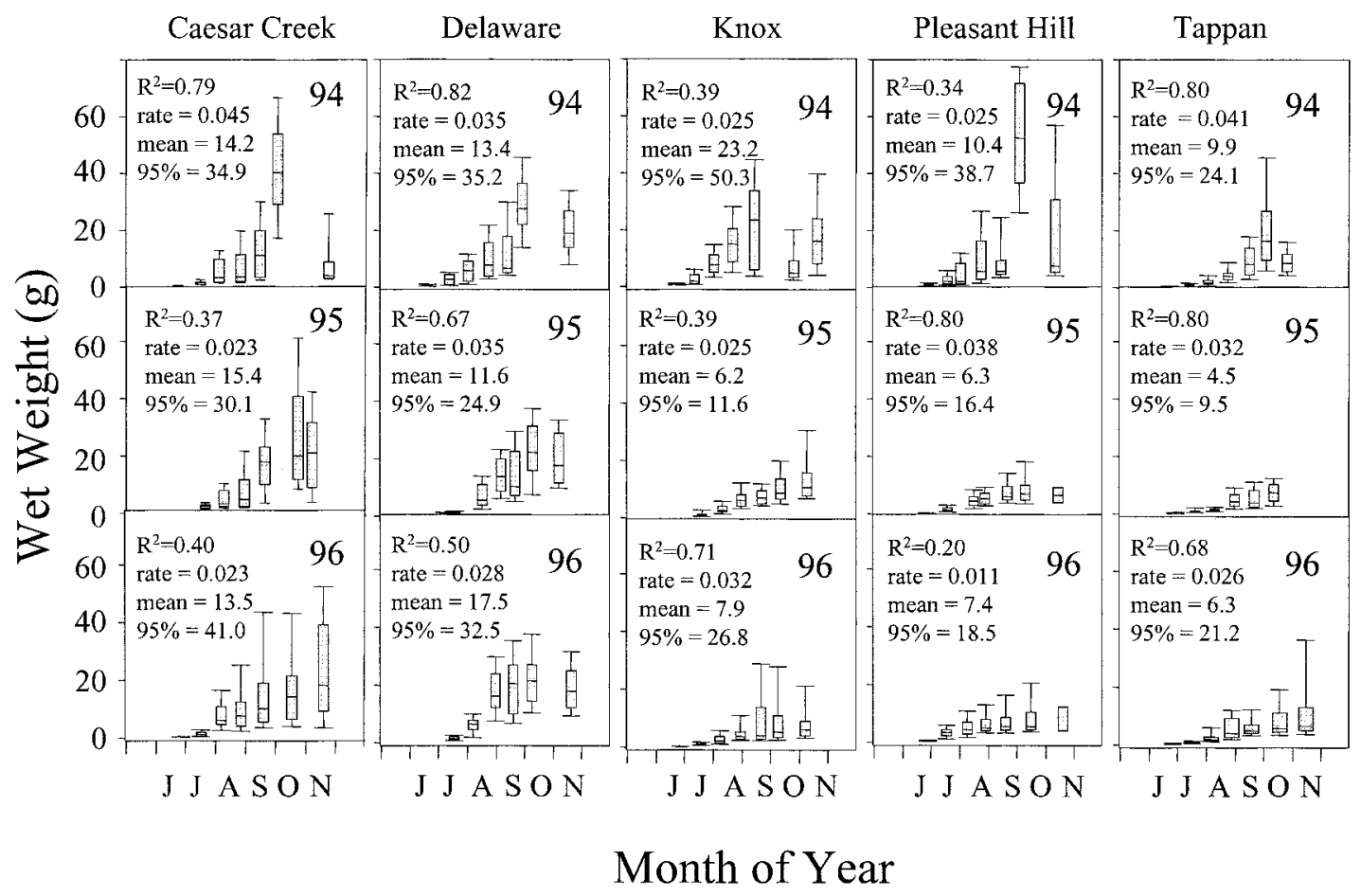

Figure 3.-Box plots of change in wet weight $(\mathrm{g})$ of age-0 largemouth bass in five Ohio reservoirs during summers of 1994-1996 ( $N>25$ for each date and reservoir), including the mean, the upper and lower quartiles as lines in the box, and the 5th and 95th percentiles as error bars. All regressions were significant (least squares, $P<0.05)$; overall daily growth rates $(\mathrm{g} / \mathrm{g})$ were derived from regression slopes assuming exponential growth and are presented below the $r^{2}$ values. Mean weights and weights of the 95 th percentiles calculated for 15 September (g) also are provided. Months are represented by initial letter (June-November); years are indicated by last two digits.

bution occurred at $10.7 \mathrm{~m}^{3} / \mathrm{s}$, after which both the variation and the mean of abundance appeared to decline (Figure 6; 2DKS: $D=0.13, P=0.1$ ). Largemouth bass abundance also appeared to decline with increasing index of May water level variation, although the pattern was only marginally significant (Figure 6; $r^{2}=0.16, P=0.1$ ). This relationship was better described by the nonparametric threshold test, where largemouth bass abundance was consistently low beyond a threshold index of May water level variation of 0.25 (Figure 6; 2DKS: $D=0.15, P=0.08$ ). During 1994 when precipitation was low, mean CPE varied among reservoirs (Figure 6). During 1995 and 1996 when precipitation was high, only in reservoirs responding with high discharge and water level variation (as a function of relative watershed area; see Figure 2) was largemouth bass abundance consistently low (Figure 6).

Several abiotic and biotic factors including precipitation may have contributed to the marked patterns of growth and diets quantified among res- ervoirs and years. In the PCA, the first three principal components explained $62.8 \%$ of the variance (Table 3). The first principal component had strong negative loadings for May precipitation and positive loadings for largemouth bass fall weight, largemouth bass CPE, the proportion of prey fish and gizzard shad in diets, and the abundance of gizzard shad (Table 3). Thus, all reservoirs but Tappan in 1994 clustered on the positive side of this principal component axis, which was associated with low May precipitation, high growth, and high piscivory (Figure 7). The second principal component had negative loadings for largemouth bass CPE, May temperature, and prey fish abundance; positive loadings occurred for relative watershed area, reservoir productivity, May discharge, largemouth bass size, and prey fish abundances in diets and in the environment (Table 3). The third principal component had positive loadings for May precipitation, productivity, discharge, gizzard shad abundance, and relative watershed area and negative loadings for summer 


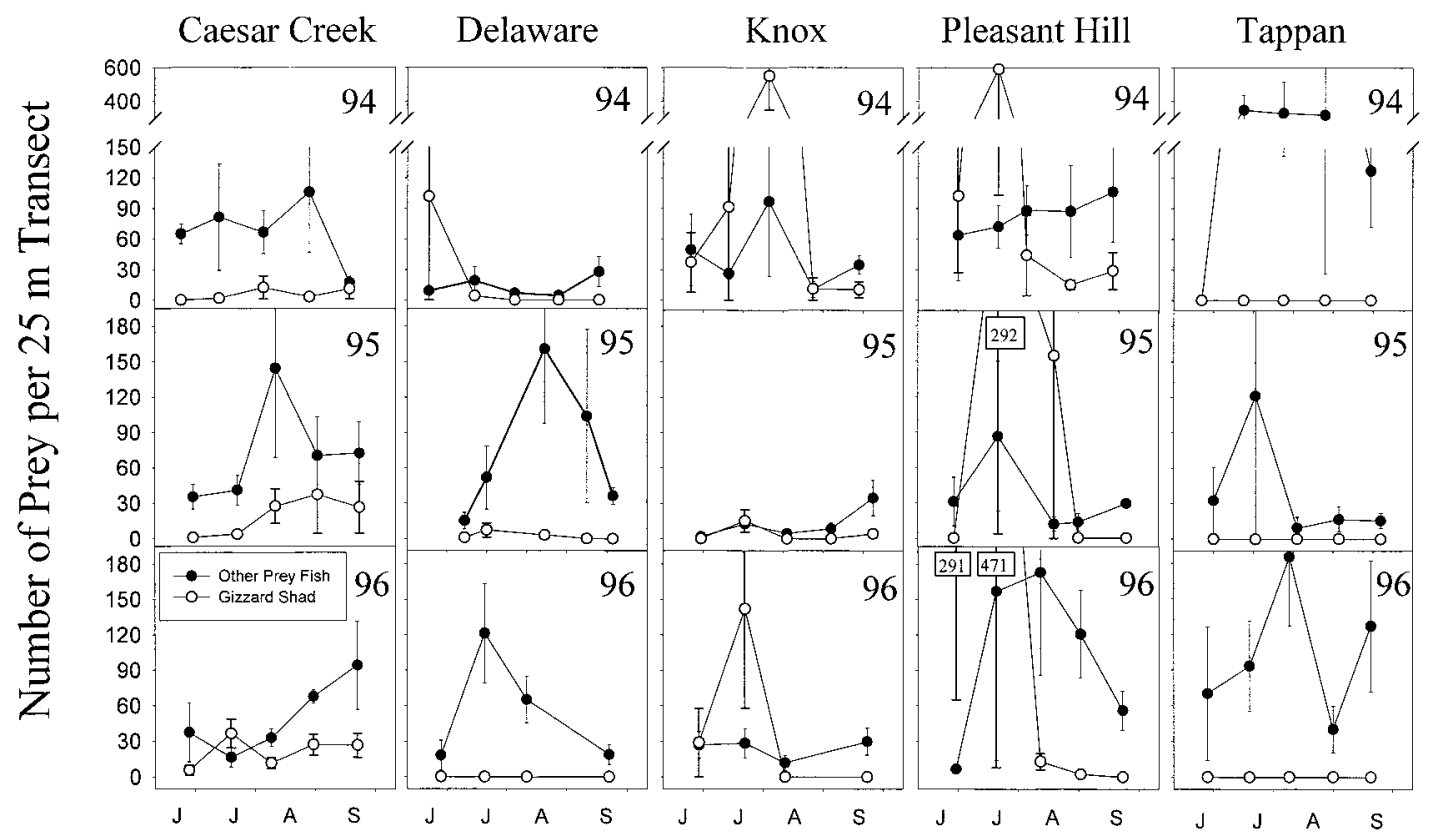

\section{Month of Year}

FIGURE 4.-Mean ( \pm SE) catch per effort (CPE; number captured/25-m inshore seining transect; $N=3-5$ transects/ reservoir) of gizzard shad (open circles) and other prey fishes (closed circles) in five Ohio reservoirs during summers 1994-1996. Fish in the Other category were mostly minnows, brook silversides, and sunfish.

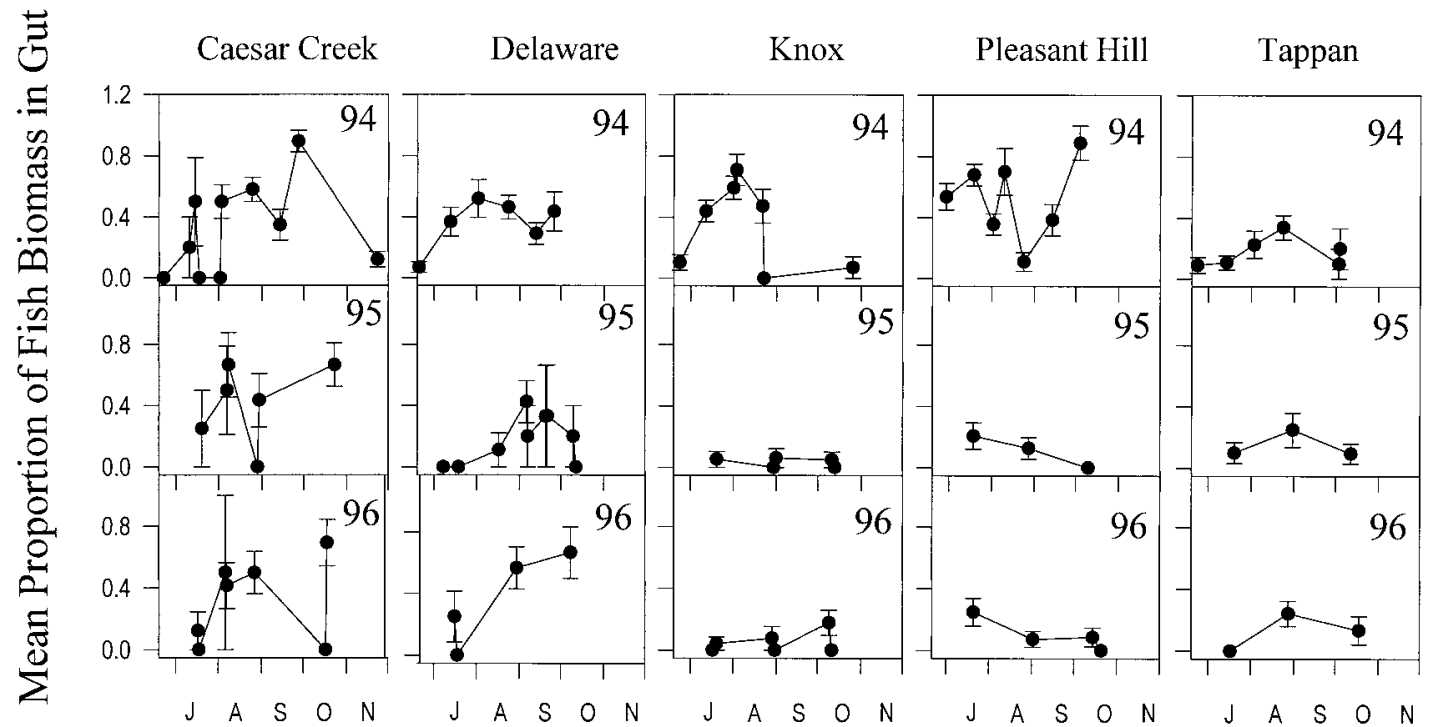

\section{Month of Year}

FIGURE 5.-Mean ( \pm SE) proportion of fish biomass ( $g$ wet weight) relative to insects and zooplankton in diets of age-0 largemouth bass in five reservoirs during summers 1994-1996. For all dates, means derive from at least 25 largemouth bass stratified by size. 
TABLE 2.-Proportion of piscivorous age-0 largemouth bass (LMB) pooled across all sampling dates within each year that contained gizzard shad (GS) versus other fish in diets for five Ohio reservoirs during 1994-1996. A $G$ test of independence ( $\mathrm{df}=2$ for all tests) determined if the proportion of gizzard shad in diets was independent of year.

\begin{tabular}{|c|c|c|c|c|c|c|}
\hline Reservoir & Year & $\begin{array}{l}\text { Number } \\
\text { of LMB }\end{array}$ & $\begin{array}{l}\text { Percent } \\
\text { GS }\end{array}$ & $\begin{array}{c}\text { Percent } \\
\text { other } \\
\text { fish }\end{array}$ & $G$ & $P^{\mathrm{a}}$ \\
\hline \multirow[t]{3}{*}{ Caesar Creek } & 1994 & 81 & 76.5 & 23.5 & 37.4 & $<0.001$ \\
\hline & 1995 & 35 & 22.9 & 77.1 & & \\
\hline & 1996 & 29 & 31.0 & 69.0 & & \\
\hline \multirow[t]{3}{*}{ Delaware } & 1994 & 73 & 57.5 & 42.5 & 23.5 & $<0.001$ \\
\hline & 1995 & 19 & 10.5 & 89.5 & & \\
\hline & 1996 & 32 & 18.8 & 81.2 & & \\
\hline \multirow[t]{3}{*}{ Knox } & 1994 & 89 & 82.0 & 18.0 & 2.2 & NS \\
\hline & 1995 & 4 & 50.0 & 50.0 & & \\
\hline & 1996 & 6 & 66.6 & 33.3 & & \\
\hline \multirow[t]{3}{*}{ Pleasant Hill } & 1994 & 98 & 62.3 & 37.7 & 15.0 & $<0.001$ \\
\hline & 1995 & 13 & 7.7 & 92.3 & & \\
\hline & 1996 & 16 & 50 & 50 & & \\
\hline \multirow[t]{3}{*}{ Tappan } & 1994 & 46 & 19.6 & 80.4 & 2.9 & NS \\
\hline & 1995 & 21 & 4.8 & 94.2 & & \\
\hline & 1996 & 22 & 18.2 & 81.8 & & \\
\hline
\end{tabular}

a NS, Not significant.

temperature and largemouth bass growth rates $(\mathrm{Ta}-$ ble 3).

For the first two principle components, Delaware and Caesar Creek in 1995 and 1996 grouped in the upper left quadrant, which corresponded to low May temperature, high reservoir productivity, high discharge, and high relative watershed size (Figure 7). This quadrant also corresponded with low largemouth bass CPE and large size (Figure 7). The remainder of reservoirs in 1995 and 1996 plus Tappan during all years, grouped in the lower left quadrant, which was related to warm May temperature, low productivity, low discharge, and small relative watershed areas (Figure 7). Interestingly, both CPE of age-0 largemouth bass and prey fish were high in these systems, suggesting that common factors facilitated production for both (Figure 7). Precipitation was the major organizing factor among years. Within the years (1995 and 1996) of high precipitation, reservoirspecific responses such as high discharge potentially reduced largemouth bass density, which may have increased growth.

\section{Discussion}

To delineate potential mechanisms and to generate predictions about growth and recruitment of age-0 fish, we must evaluate the relative effect of abiotic and biotic factors at appropriate spatial and temporal scales (see Tonn et al. 1990). Below, we discuss how regional patterns of spring precipitation interacted with local, reservoir-specific processes to influence age- 0 largemouth bass abundance and growth in Ohio reservoirs.

\section{Low Spring Precipitation}

Both our univariate and multivariate statistical approaches revealed that the regionally low precipitation in spring 1994 was associated with large fall sizes of age- 0 largemouth bass in reservoirs. In addition, abundances of age- 0 largemouth bass were relatively high in most reservoirs during 1994. Growth rates and fall sizes were generally unrelated, suggesting that a long growing period rather than rapid accumulation of biomass contributed to observed patterns (Donovan et al. 1997). Although hatch dates for these fish are unknown, the large individuals in fall 1994 may have hatched relatively early, thereby growing over a long period of time and exploiting a large range of prey sizes, including gizzard shad during the growing season (Goodgame and Miranda 1993). Both discharge and water level fluctuations were low in all reservoirs during spring 1994, indicating that water conditions were relatively quiescent. We hypothesize that factors linked to these stable water conditions facilitated early production of age0 largemouth bass across reservoirs in 1994.

Stable water conditions may have facilitated reproduction of adults in 1994 and thus enhanced offspring abundance. To illustrate, if water levels rise over nests beyond some threshold depth ( $>1 \mathrm{~m}$; Heidinger 1975; Kohler et al. 1993), adult largemouth bass will abandon them, returning later to spawn again. This mechanism may have reduced production of age-0 largemouth bass in some reservoirs in 1995 and 1996, when such water level fluctuations occurred (i.e., Delaware and Caesar Creek). Converse- 

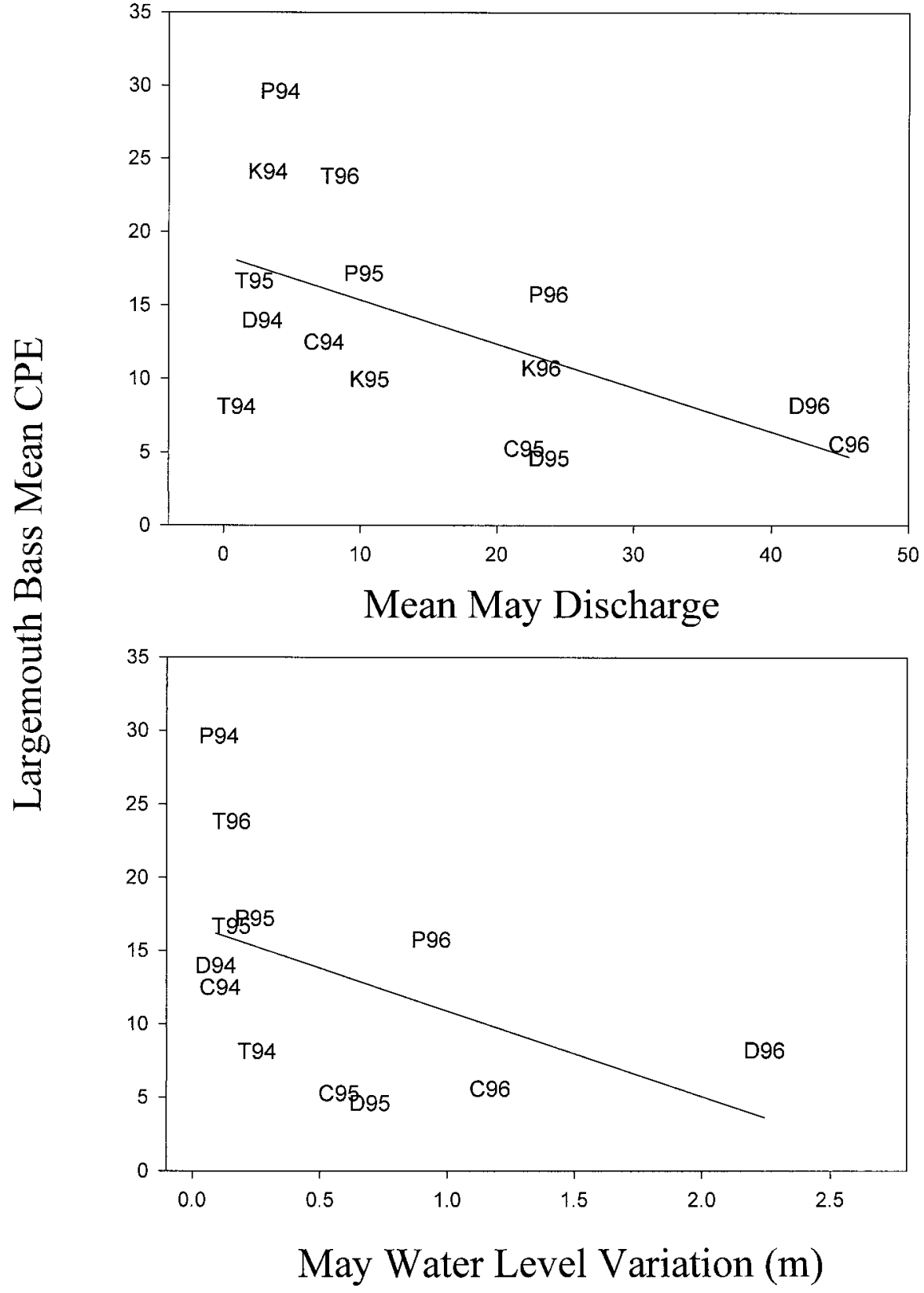

Figure 6.-Mean May daily discharge ( $\mathrm{m}^{3} / \mathrm{s}$; top panel) and index of May water level fluctuations (see Figure 1 for definition; bottom panel) versus estimated age-0 largemouth bass abundance (mean electrofishing catch per effort (CPE) across 4-5 dates during August-October) in five Ohio reservoirs during 1994-1996 (top: $r^{2}=0.27$, $P=0.03$; bottom: $\left.r^{2}=0.16, P=0.1\right)$. Reservoir codes correspond to the first letter of the reservoir name (P, Pleasant Hill; C, Caesar Creek; D, Delaware; K, Knox; and T, Tappan) plus the last two digits of the year.

ly, stable water conditions such as those in 1994 may have facilitated reproductive success. Tappan Lake was the only reservoir that did not respond to low precipitation in 1994 by producing abundant age-0 largemouth bass. Apparently, other factors limited reproductive success that year. Due to its relatively small watershed, discharge in Tappan was low and only weakly related to precipitation. Stable conditions in Tappan in 1995 and 1996 relative to other reservoirs likely did enhance overall reproductive 
TABLE 3.-Eigenvalues and eigenvectors of the first three principal components generated by a principal components analysis (PCA). The PCA incorporated 14 abiotic and biotic factors that varied across five Ohio reservoirs during 19941996. Loadings ranging from 0 to 0.25 and from -0.25 to 0 are denoted by plus and minus signs, respectively. Abbreviations are as follows: LMB, largemouth bass; CPE, catch per effort; TP, total phosphorus.

\begin{tabular}{lccc}
\hline \multicolumn{1}{c}{ Statistic or variable } & PC1 & PC2 & PC3 \\
\hline Eigenvalue & 3.821 & 2.799 & 2.166 \\
Percent variance & 27.3 & 19.9 & 15.5 \\
Variable & & & \\
May precipitation & -0.413 & - & 0.269 \\
May temperature & + & -0.289 & + \\
Summer temperature & - & + & -0.346 \\
Watershed area : surface area & + & 0.269 & 0.499 \\
Reservoir productivity (TP) & - & 0.314 & 0.399 \\
May discharge & - & 0.326 & 0.287 \\
LMB CPE & 0.305 & -0.309 & + \\
LMB daily growth rate (g/g) & + & + & -0.325 \\
LMB mean fall wet weight (g) & 0.299 & 0.374 & - \\
LMB 95\% fall wet weight (g) & 0.379 & 0.319 & - \\
Percent LMB with fish in diets & 0.311 & 0.369 & - \\
Percent LMB with shad in diets & 0.377 & - & - \\
Prey fish CPE & + & -0.266 & + \\
Shad CPE & 0.301 & - & 0.359 \\
\hline
\end{tabular}
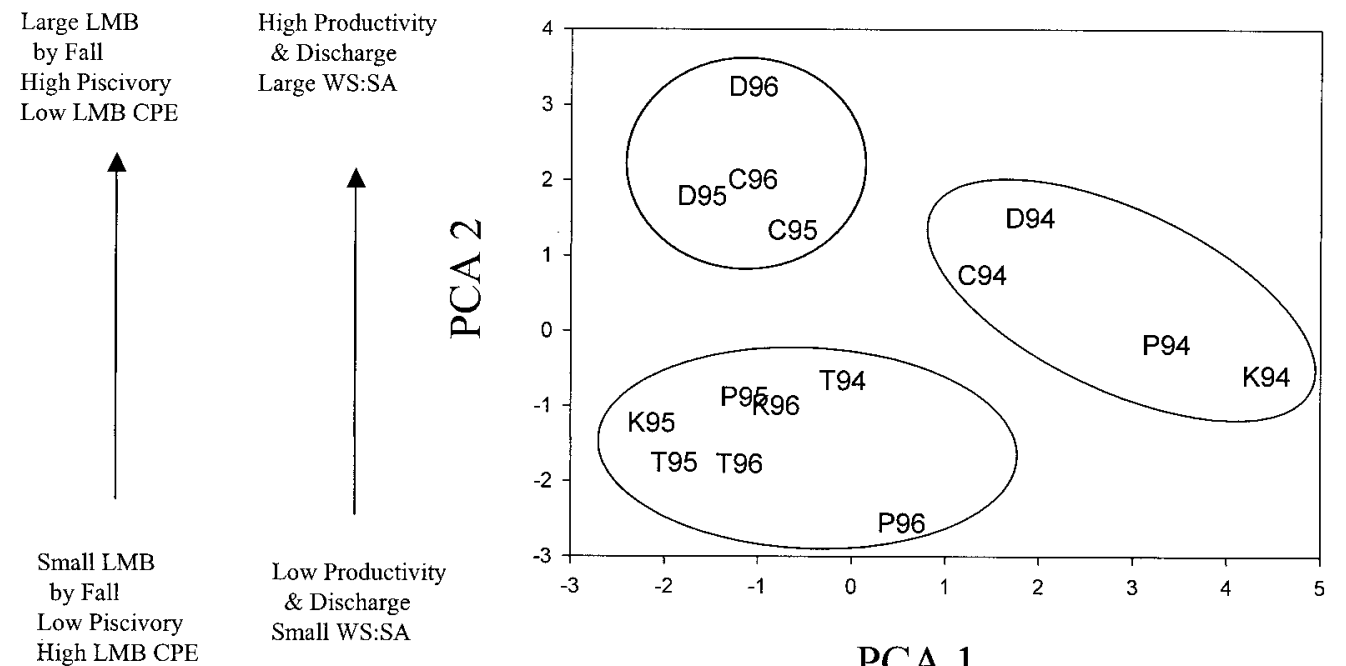

High LMB CPE

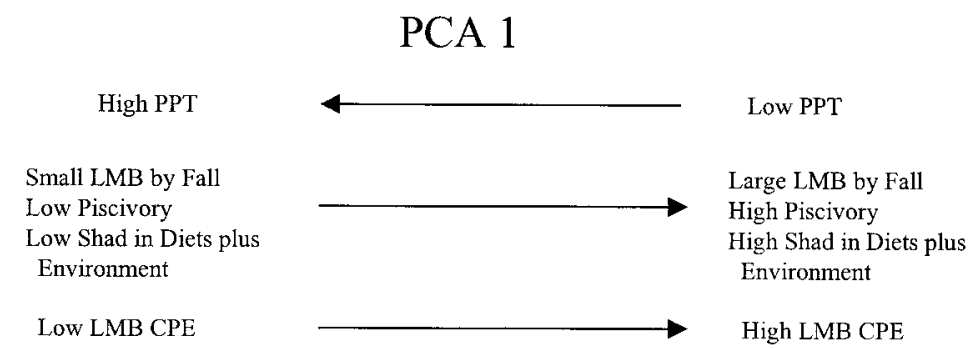

FiguRE 7.-Loadings of first two principal components explaining $29.4 \%$ and $21.1 \%$ of the variance in 13 abiotic and biotic variables associated with five Ohio reservoirs in 1994, 1995, and 1996. Variables associated with each principal component axis with loadings greater than 0.25 or less than -0.25 are denoted (see Table 3 for list of variables and associated loadings). Reservoir codes are defined in Figure 6. Abbreviations are as follows: PPT, precipitation; LMB, largemouth bass; WS : SA, ratio of watershed area to reservoir surface area; CPE, catch per unit effort. 
success and offspring numbers in this system. Reservoir hydrology and, in particular, stable spring water levels may influence recruitment by driving reproductive (Rulifson and Manooch 1990; Maceina 1997; Slipke et al. 1998) and recruitment success (Maceina and Bettoli 1998).

Stable reservoir water levels in 1994 also likely facilitated the switch to piscivory by age-0 largemouth bass, thereby contributing to their growth. Indeed, gizzard shad were prevalent in diets of age-0 largemouth bass in all systems but Tappan Lake. A large proportion of gizzard shad may have been vulnerable during this year because largemouth bass possessed a size advantage. However, our analysis of size overlap between gizzard shad and largemouth bass did not reveal differences among reservoirs and years. Gizzard shad size distributions in this analysis derived from seining. Because capture success of gizzard shad was extremely variable among dates and sites, the inefficiency of seining for this species may generate a poor estimate of sizes encountered by largemouth bass. If stable water levels facilitated early hatching of a large proportion of age-0 largemouth bass, these individuals may have had sufficient time to grow to a piscivorous size before fish prey appeared (Adams et al. 1982; Adams and DeAngelis 1987; Garvey and Stein 1998b).

\section{High Spring Precipitation}

During 1995 and 1996 when May precipitation was high, discharge and water level fluctuations differed among reservoirs, in part as a function of their relative watershed area. These reservoirspecific hydrological responses translated to different abundances of age-0 largemouth bass, most likely through the effect of water level on reproductive success. Interestingly, although no densitydependent patterns of largemouth bass growth were detected across reservoirs in 1994, growth of age-0 largemouth bass was negatively related to their abundance across reservoirs in 1995 and 1996 when other prey fishes or benthic invertebrates dominated in diets. During 1995 and 1996, densities of largemouth bass were low in reservoirs with high discharge and water level fluctuations (e.g., Delaware), in which both growth rates, as suggested by the PCA, and fall sizes, as revealed by the univariate procedure, were high. Perhaps low spring densities of age-0 largemouth bass prevented them from overexploiting prey, thereby facilitating growth. In systems with relatively small watersheds, particularly Tappan reservoir in which age-0 largemouth bass densities were high in 1995 and 1996, intraspecific competition for limited resources may have compromised growth. Thus, how individual reservoirs responded to regional precipitation drove biotic interactions and potentially recruitment of largemouth bass. Other factors, such as position of the reservoir in the watershed and degree of development, may further resolve our understanding of physical responses to precipitation and the implications for largemouth bass recruitment.

\section{Other Potential Mechanisms}

Other factors may have contributed to reservoirspecific patterns of growth. We initially predicted that high prey fish abundance comprised primarily of gizzard shad would increase largemouth bass piscivory and growth. Plotting the first two principle components in the PCA did reveal some correspondence between large largemouth bass sizes, piscivory, and shad density. During the other years, strong relationships were not detected; in fact, the PCA suggested that prey fish abundance and largemouth bass growth were negatively related. Certainly more resolution for assessing prey fish availability to largemouth bass was required.

System-specific temperatures during May and during the summer may have affected patterns of growth among reservoirs. The second principle component revealed a correspondence between cool May temperatures and large largemouth bass fall sizes. This pattern is difficult to interpret, because we might expect warm springs to facilitate early spawning and long growing seasons. Though loadings for rapid largemouth bass growth rates and warm summer temperatures corresponded in the third principle component, preliminary bioenergetics modeling of age- 0 largemouth bass growth during summers as a function of reservoirspecific temperatures provided little additional insight into observed patterns of growth (generalized Wisconsin model; Hanson et al. 1997; Garvey, unpublished data).

During years of high precipitation, reservoirs with large fall sizes and high reservoir productivity were grouped by the PCA, suggesting that increased reservoir productivity increased biomass accumulated by fall. High spring water levels may provide foraging opportunities and refuge for age0 largemouth bass and other fishes by inundating terrestrial vegetation, thereby facilitating their early growth and survival (Miranda et al. 1984; Poizat and Crivelli 1997; Sammons et al. 1999). As such, the high water level fluctuations in some reservoirs in 1995 and 1996 may have contributed to rapid 
growth rates and large fall sizes through this mechanism, although uncontrolled variation in water levels may have reduced their abundance by hindering reproduction.

\section{Implications}

Unraveling mechanisms underlying recruitment requires an understanding of how regional and local scale factors interact to affect growth and survival during early ontogeny. Large-scale climatic conditions interacting with reservoir hydrology may well set the stage for piscivory and growth of largemouth bass. The frequency of these regional events may drive much of the interannual variability in cohort strength. If May precipitation contributes to these patterns, just how typical 1994 was becomes important because high abundances of large age-0 largemouth bass were produced in most reservoirs during this year. Combining May precipitation data across 48 years (1949-1996; U.S. National Weather Service) in central Ohio revealed that years in our study spanned the range from dry to wet years. Median total precipitation for May was $8.8 \mathrm{~cm}$ across years; $1995(12.3 \mathrm{~cm})$ and $1996(13.1 \mathrm{~cm})$ were wetter than most years, whereas $1994(4.3 \mathrm{~cm})$ was drier. If a dry May is necessary for the biotic interactions we documented to occur, the historical analysis revealed that $<15 \%$ of years should be expected to produce appropriate conditions for rapid largemouth bass growth and successful recruitment. If global climate change alters future precipitation patterns in Ohio (see Matyasovszky and Bogardi 1996; Krupa 1997), our ability to predict successful largemouth bass recruitment will be compromised. At present, water levels are not managed for fish in these systems. As has been suggested for other systems (Miranda et al. 1984), management that reduces water level fluctuations during May should facilitate largemouth bass recruitment.

If water levels cannot be controlled, we may predict that gizzard shad will not be consumed by age-0 largemouth bass during most years. Local, density-dependent processes appeared to influence predation on other prey fishes and growth of age0 largemouth bass during years when spring discharge and water level fluctuations were high. Hence, poor early (i.e., egg or larval) survival may translate to rapid growth rates and large fall sizes, but low densities. Conversely, high early survival translates to poor first-summer growth, which likely increases the probability of overwinter mortality (Adams et al. 1982; Johnson and Evans 1990; Bernard and Fox 1997; Garvey et al. 1998c). In par- ticular, more small ( $<125 \mathrm{~mm}$ total length) than large age-0 largemouth bass in Knox and Pleasant Hill died during winter 1994-1995, suggesting that small fall size indeed leads to poor recruitment in these systems (Garvey et al. 1998c). The magnitude of size-selective winter mortality may vary as a function of variable local factors such as predation (Miranda and Hubbard 1994; Garvey et al. 1998c).

Given our results plus the historical precipitation pattern, cohort strength of largemouth bass should generally be low in Ohio reservoirs dominated by gizzard shad (Stein et al. 1988; Persson and Greenberg 1990; Olson et al. 1995; Ludsin and DeVries 1997). As Miranda et al. (1984) suggest, enhanced prey fish production coupled with strong early survival should improve largemouth bass recruitment. Work that explores systemspecific factors such as (1) local mechanisms underlying the early growth and survival of gizzard shad (Stein et al. 1996), (2) competitive interactions between gizzard shad and other prey fishes (see DeVries and Stein 1992; Garvey et al. 1998a; Garvey and Stein 1998a for examples in small reservoirs), and (3) prey fish-habitat interactions (Jones et al. 1996; Minns et al. 1996) may be necessary to devise management strategies that improve largemouth bass recruitment.

\section{Acknowledgments}

We thank Heather McCann, Mike McKee, Kristen Morrison, Rick Ginsberg, and Stephanie Micucci for their efforts in the field and laboratory. Randall Schultz, Paul Michaletz, David Conover, and three anonymous reviewers provided helpful comments on an earlier version of this manuscript. This research was funded by National Science Foundation grant DEB 9407859 to RAS and Federal Aid in Sport Fish Restoration project F-69-P, administered jointly by the U.S. Fish and Wildlife Service and the Ohio Division of Wildlife. A Postdoctoral Fellowship and Presidential Fellowship from The Ohio State University supported RAW and JEG, respectively, during part of this work.

\section{References}

Adams, S. M., and D. L. DeAngelis. 1987. Indirect effects of early bass-shad interactions on predator population structure and food-web dynamics. Pages 103-117 in W. C. Kerfoot and A. Sih, editors. Predation: direct and indirect impacts on aquatic communities. University Press of New England, Hanover, New Hampshire.

Adams, S. M., R. B. McLean, and M. M. Huffman. 1982. Structuring of a predator population through tem- 
perature-mediated effects on prey availability. $\mathrm{Ca}-$ nadian Journal of Fisheries and Aquatic Sciences 39:1175-1184.

Bernard, G., and M. G. Fox. 1997. Effects of body size and population density on overwinter survival of age-0 pumpkinseeds. North American Journal of Fisheries Management 17:581-590.

Bremigan, M. T. 1997. Variable recruitment of gizzard shad, a strong interactor in reservoirs: exploring causal mechanisms and implications for food webs. Doctoral dissertation. The Ohio State University, Columbus.

Bremigan, M. T., and R. A. Stein. 1994. Gape-dependent larval foraging and zooplankton size: implications for fish recruitment across systems. Canadian Journal of Fisheries and Aquatic Sciences 51:913-922.

Carpenter, S. R. 1999. Microcosm experiments have little relevance for community and ecosystem ecology: reply. Ecology 80:1085-1088.

Chambers, R. C., and E. A. Trippel. 1997. Early life history and recruitment: legacy and challenges. Pages 516-549 in R. C. Chambers and E. A. Trippel, editors. Early life history and recruitment in fish populations. Chapman and Hall, New York.

Culver, D. A., M. M. Boucherle, D. J. Bean, and J. W. Fletcher. 1985. Biomass of freshwater crustacean zooplankton from length-weight regressions. Canadian Journal of Fisheries and Aquatic Sciences 42:1380-1390.

Dettmers, J. M., and R. A. Stein. 1996. Quantifying linkages among gizzard shad, zooplankton, and phytoplankton in reservoirs. Transactions of the American Fisheries Society 125:27-41.

DeVries, D. R., and R. F. Frie. 1996. Determination of age and growth. Pages 483-512 in B. R. Murphy and D. W. Willis, editors. Fisheries techniques, 2nd edition. American Fisheries Society, Bethesda, Maryland.

DeVries, D. R., and R. A. Stein. 1992. Complex interactions between fish and zooplankton: quantifying the role of an open-water planktivore. Canadian Journal of Fisheries and Aquatic Sciences 49:12121227.

Donovan, N. S., R. A. Stein, and M. M. White. 1997. Enhancing percid stocking success by understanding age-0 piscivore-prey interactions in reservoirs. Ecological Applications 7:1311-1329.

Drenner, R. W., and A. Mazumder. 1999. Microcosm experiments have limited relevance for community and ecosystem ecology: comment. Ecology 80: 1081-1084.

Dumont, H., J. I. V. d. Velde, and S. Dumont. 1975. The dry weight estimates of biomass in selection of Cladocera, Copepoda and Rotifera from the plankton, periphyton, and benthos of continental waters. Oecologia 19:75-97.

Forney, J. L. 1976. Year-class formation in the walleye (Stizostedion vitreum vitreum) population of Oneida Lake, New York, 1966-1973. Journal of the Fisheries Research Board of Canada 33:783-792.

Garvey, J. E., N. A. Dingledine, N. S. Donovan, and R. A. Stein. 1998a. Exploring spatial and temporal variation within reservoir food webs: predictions for fish assemblages. Ecological Applications 8:104120.

Garvey, J. E., E. A. Marschall, and R. A. Wright. 1998b. From star charts to stoneflies: detecting relationships in continuous bivariate data. Ecology 79:442447.

Garvey, J. E., and R. A. Stein. 1998a. Competition between larval fishes in reservoirs: the role of relative timing of appearance. Transactions of the American Fisheries Society 127:1023-1041.

Garvey, J. E., and R. A. Stein. 1998b. Linking bluegill and gizzard shad prey assemblages to growth of age0 largemouth bass in reservoirs. Transactions of the American Fisheries Society 127:70-83.

Garvey, J. E., R. A. Wright, and R. A. Stein. 1998c. Overwinter growth and survival of age- 0 largemouth bass: revisiting the role of body size. Canadian Journal of Fisheries and Aquatic Sciences 55:2414-2424.

Garvey, J. E., R. A. Wright, R. A. Stein, E. M. Lewis, K. H. Ferry, and S. M. Micucci. 1998d. Assessing the influence of size on overwinter survival of largemouth bass in Ohio on-stream impoundments. Ohio Division of Wildlife, Federal Aid in Sport Fish Restoration, Program 29, Final Report, Columbus.

Goodgame, L. S., and L. E. Miranda. 1993. Early growth and survival of age- 0 largemouth bass in relation to parental size and swim-up time. Transactions of the American Fisheries Society 122:131-138.

Hambright, K. D., R. W. Drenner, S. R. McComas, and N. G. Hairston, Jr. 1991. Gape-limited piscivores, planktivore size refuges, and the trophic cascade hypothesis. Archive für Hydrobiologie 121:389404.

Hanson, P. C., T. B. Johnson, D. E. Schindler, and J. F. Kitchell. 1997. Fish Bioenergetics 3.0. University of Wisconsin, Sea Grant Institute, Madison.

Heidinger, R. C. 1975. Life history and biology of the largemouth bass. Pages 11-20 in H. Clepper, editor. Black bass biology and management. Sport Fishing Institute, Washington, D.C.

Hilborn, R., C. J. Walters, and D. Ludwig. 1995. Sustainable exploitation of renewable resources. Annual Review of Ecology and Systematics 26:45-67.

Holland-Bartels, L. E., S. K. Littlejohn, and M. L. Huston. 1990. A guide to the larval fishes of the upper Mississippi River. U.S. Fish and Wildlife Service Publication, LaCrosse, Wisconsin.

Johnson, T. B., and D. O. Evans. 1990. Size-dependent winter mortality of young-of-the-year white perch: climate warming and invasion of the Laurentian Great Lakes. Transactions of the American Fisheries Society 119:301-313.

Jones, M. L., R. G. Randall, D. Hayes, W. Dunlop, J. Imhof, G. Lacroix, and N. J. R. Ward. 1996. Assessing the ecological effects of habitat change: moving beyond productive capacity. Canadian Journal of Fisheries and Aquatic Sciences 53(Supplement 1):446-457.

Juanes, F. 1994. What determines prey size selectivity in piscivorous fishes? Pages 79-100 in D. J. Stoud- 
er, K. L. Fresh, and R. J. Feller, editors. Theory and application in fish feeding ecology. University of South Carolina Press, Columbia.

Kohler, C. C., R. J. Sheehan, and J. J. Sweatman. 1993. Largemouth bass hatching success and first-winter survival in two Illinois reservoirs. North American Journal of Fisheries Management 13:125-133.

Krupa, S. V. 1997. Global climate change: processes and products-an overview. Environmental Monitoring and Assessment 46:1-2.

Leggett, W. C., K. T. Frank, and J. E. Carscadden. 1984. Meteorological and hydrographic regulation of year-class strength in capelin (Mallotus villosus). Canadian Journal of Fisheries and Aquatic Sciences 41:1193-1201.

Ludsin, S. A., and D. R. DeVries. 1997. First-year recruitment of largemouth bass: the inter-dependency of early life stages. Ecological Applications 7: $1024-1038$.

Maceina, M. J. 1997. Simple application of using residuals from catch-curve regressions to assess yearclass strength in fish. Fisheries Research 32:115121.

Maceina, M. J., and P. W. Bettoli. 1998. Variation in largemouth bass recruitment in four mainstream impoundments of the Tennessee River. North American Journal of Fisheries Management 18:998-1003.

Matyasovszky, I., and I. Bogardi. 1996. Downscaling two versions of a general circulation model to estimate local hydroclimatic factors under climate change. Hydrological Sciences Journal 41:117-129.

Michaletz, P. A. 1997. Influence of abundance and size of age-0 gizzard shad on predator diets, diet overlap, and growth. Transactions of the American Fisheries Society $126: 101-111$.

Minns, C. K., J. R. M. Kelso, and R. G. Randall. 1996. Detecting the response of fish to habitat alterations in freshwater ecosystems. Canadian Journal of Fisheries and Aquatic Sciences 53(Supplement 1):403414.

Miranda, L. E., and W. D. Hubbard. 1994. Winter survival of age-0 largemouth bass relative to size, predators and shelter. North American Journal of Fisheries Management 14:790-796.

Miranda, L. E., W. L. Shelton, and T. D. Bryce. 1984. Effects of water level manipulation on abundance, mortality and growth of young-of-year largemouth bass in West Point Reservoir, Alabama and Georgia (USA). North American Journal of Fisheries Management 4:314-320.

Mittelbach, G. G., A. M. Turner, D. J. Hall, J. E. Rettig, and C. W. Osenberg. 1995. Perturbation and resilience: a long-term, whole-lake study of predator extinction and reintroduction. Ecology 76:23472360.

Olson, M. H., G. G. Mittelbach, and C. W. Osenberg. 1995. Competition between predator and prey: resource-based mechanisms and implications for stage-structured dynamics. Ecology 76:1758-1771.

Persson, L., and L. A. Greenberg. 1990. Juvenile competitive bottlenecks: the perch (Perca fluviatilis)- roach (Rutilus rutilus) interaction. Ecology 71:4456.

Poizat, G., and A. J. Crivelli. 1997. Use of seasonally flooded marshes by fish in a Mediterranean wetland: timing and demographic consequences. Journal of Fish Biology 51:106-119.

Rose, G. A., and W. C. Leggett. 1990. The importance of scale to predator-prey spatial correlations: an example of Atlantic fishes. Ecology 71:33-43.

Rulifson, R. A., and C. S. Manooch III. 1990. Recruitment of juvenile striped bass in the Roanoke River, North Carolina (USA), as related to reservoir discharge. North American Journal of Fisheries Management 10:397-407.

Sammons, S. M., L. G. Dorsey, P. W. Bettoli, F. C. Fiss. 1999. Effects of reservoir hydrology on reproduction by largemouth bass and spotted bass in Normandy Reservoir, Tennessee, North American Journal of Fisheries Management 19:78-88.

SAS Institute. 1990. SAS/STAT user's guide, version 6, 4th edition. Statistical Analysis Systems Institute, Cary, North Carolina.

Schael, D. M., L. G. Rudstam, and J. R. Post. 1991. Gape limitation and prey selection in larval yellow perch (Perca flavescens), freshwater drum, (Aplodinotus grunniens), and black crappie (Pomoxis nigromaculatis). Canadian Journal of Fisheries and Aquatic Sciences 38:1919-1925.

Slipke, J. W., M. J. Maceina, D. R. DeVries, and F. J. Snow. 1998. Effects of shad density and reservoir hydrology on the abundance and growth of youngof-year crappie in Alabama reservoirs. Journal of Freshwater Ecology 13:87-95.

Smock, L. A. 1980. Relationships between body size and biomass of aquatic insects. Freshwater Biology 10:375-383.

Sokal, R. R., and F. J. Rohlf. 1981. Biometry: the principles and practice of statistics in biological research. Freeman Press, New York.

Stahl, T. P., and R. A. Stein. 1994. Influence of larval gizzard shad (Dorosoma cepedianum) density on piscivory and growth of young-of-year saugeye (Stizostedion vitreum $\times S$. canadense). Canadian Journal of Fisheries and Aquatic Sciences 51:1993-2002.

Stein, R. A., M. T. Bremigan, and J. M. Dettmers. 1996. Understanding reservoir systems with experimental tests of ecological theory: a prescription for management. Pages 12-22 in L. E. Miranda and D. R. DeVries, editors. Multidimensional approaches to reservoir fisheries management. American Fisheries Society, Special Publication 16, Bethesda, Maryland.

Stein, R. A., D. R. DeVries, and J. M. Dettmers. 1995. Food web regulation by a planktivore: exploring the generality of the trophic cascade hypothesis. Canadian Journal of Fisheries and Aquatic Sciences 52:2518-2526.

Stein, R. A., S. T. Threlkeld, C. D. Sandgren, W. G. Sprules, L. Persson, E. E. Werner, W. E. Neill, and S. I. Dodson. 1988. Size-structured interactions in lake communities. Pages 161-180 in S. R. Carpen- 
ter, editor. Complex interactions in lake communities. Springer-Verlag, New York.

Thornton, K. W. 1990. Perspectives on reservoir limnology. Pages 1-13 in K. W. Thornton, B. L. Kimmel, and F. E. Payne, editors. Reservoir limnology: ecological perspectives. Wiley, New York.

Tonn, W. M., J. J. Magnuson, M. Rask, and J. Toivonen.
1990. Intercontinental comparison of small-lake fish assemblages: the balance between local and regional processes. American Naturalist 136:345-375.

Wahl, D. H., and R. A. Stein. 1991. Food consumption and growth of three esocids: field tests of a bioenergetics model. Transactions of the American Fisheries Society 120:230-246. 